\title{
Vegetation history and salinity gradient during the last 3700 years in Pichavaram estuary, India
}

\author{
Jyoti Srivastava ${ }^{1, *}$, Anjum Farooqui ${ }^{1}$ and S M Hussain ${ }^{2}$ \\ ${ }^{1}$ Birbal Sahni Institute of Palaeobotany, 53 University Road, Lucknow 226 007, India. \\ ${ }^{2}$ University of Madras, A.C. College Campus, Chennai 600 025, India. \\ *Corresponding author. e-mail: caprice2628@yahoo.com
}

Palaeoclimate, palaeoecological and palaeoshoreline studies were carried out for a $2.5 \mathrm{~m}$ deep sediment core deposited since $\sim 3700$ yrs BP in the central part of Pichavaram mangrove wetland, Cauvery river delta. Presently, the study area is dominated by Avicennia officinalis, A. marina and Suaeda sp. with fringes of Rhizophora sp. along the backwater channel. Based on sedimentology, palynological and thecamoebian analysis, it is inferred that since $2100 \mathrm{yrs}$ BP the climate amelioration took place from warm and humid with strengthened monsoon to a dry and arid climate coupled with weakened monsoon condition inducing changes in ecology vulnerable for mangroves. Consequently, the vegetation too evolved from moist deciduous/evergreen forest to mixed deciduous forest and a reduction in mangrove diversity. The qualitative and quantitative study show a decline in the mangroves since the last millennium which may be attributed to the increased salinity along with enhanced anthropogenic activities in Pichavaram estuary. This is reflected by the dominance of salt tolerant mangrove associates since the last millennium.

\section{Introduction}

The Pichavaram mangrove wetland is highly productive and occupies the intertidal zone in a tropical region, characterized by small topographic gradients and large tidal amplitude. The sediment dynamics in such an ecosystem is largely regulated by internal (flocculation, dissolution, mixing, etc.) as well as external (e.g., river input, agricultural run-off, pollution) factors. The interactions of mangrove plants and sediments are complex and dynamic as they deal with a harsh saline intertidal environment (Saenger 2002) despite degradation by human activities (Klekowski et al. 1994) and by natural disturbances (Seralathan et al. 2006). Anthropogenic pressures and sea level changes control the mechanism of salt-water intrusion and freshwater run-off and the fate of mangroves in the low-lying deltaic areas along the south-east coast of India (figure 1b). The soil is frequently flooded and well drained in the Pichavaram estuary which supports luxuriant growth of mangroves. The tidal amplitude of sea and freshwater input keeps up an ecological balance for the sustenance of this specialized ecosystem along this coast. The composition of mangroves is mainly determined by the tolerance of different species to substrate and saline conditions, which in turn determines the dominance of one or various species at a specific site. At present, most of the estuaries and near shore wetlands along the south-eastern Indian coast are covered by salinity tolerant mangrove species such as Avicennia and Suaeda spp. Most of the areas along the south-eastern coast were inhabited by diverse species of mangroves in the past (Farooqui and Vaz 2000; Farooqui and Achyuthan 2006) which are now either on the verge of decline or have migrated to more conducive areas in small

Keywords. Late-Holocene; palynology; thecamoebians; Pichavaram; India. 
pockets due to rapid changes in the habitat. Thus there is a need of more focused research on the lowlying landforms along the south-east coast vulnerable to a range of salinity pressures. The present study reconstructs the past vegetation changes and changes in the salinity gradient associated to the changes in the NE-palaeomonsoon and in the intensity of human impact during the last 3700 years in SE India. These data will contribute to fill a gap in south-India where Holocene records are meagre.

\section{Description of the study area}

The Pichavaram mangrove wetland (latitude $11^{\circ} 25^{\prime} \mathrm{N}$ and longitude $79^{\circ} 47^{\prime} \mathrm{E}$ ) is a shallow estuarine complex sandwiched between two prominent estuaries, the Vellar estuary in the north and Coleroon estuary in the south with a total area of 1100 ha. It has 15 islets ranging in size from $10 \mathrm{~m}^{2}$ to $2 \mathrm{~km}^{2}$ separated by intricate waterways that connect the Vellar estuary in the north and the Coleroon estuary in the south (Ramanathan 1997). The Coleroon estuary part is largely dominated by mangroves, while the Vellar estuary is dominated by mud-flats. Tidal water enters the Pichavaram mangrove through a small direct connection with the Bay of Bengal at Chinnavaikal and estuarine water finds its way through the two adjacent river systems. Avicennia marina is the most dominant mangrove species followed by Avicennia officinalis, Excoecaria agallocha, Rhizophora apiculata and Rhizophora mucronata. The tides in the Pichavaram mangroves are semi-diurnal and vary in amplitude from 0.15 to $1 \mathrm{~m}$ (Kathiresan 2000).

The study area consists of flood plain, sedimentary plain and beach sand. Most of the soil along the western part is alluvium whereas fluvial marine and beach sand dominates in the eastern part. The climate is sub-humid and the ratio of precipitation to evapo-transpiration $(\mathrm{P} / \mathrm{Etp})$ ranges from 0.5 0.75 (Selvam 2003) with maximum precipitation all through the northeast monsoons. The annual temperature variation is $18.2^{\circ}-36^{\circ} \mathrm{C}$. The biogeochemical processes in this ecosystem are governed by a heavy input of sediments and anthropogenic discharges from the Vellar and Coleroon rivers. Uppanar River and Khan Saheb Canal contribute the discharge during monsoon season. The main reason for the changed landscape in the recent past is perhaps the introduction of irrigation and hydrological works in the rivers of the Cauvery delta system, which caused the change in water supply (Ferdin et al. 2010). This resulted in a reduction of water discharge downstream in the river. Thus the recent environmental changes in this area can be attributed to human activities rather than natural climatic development.

\section{Materials and method}

A $2.5 \mathrm{~m}$ deep sediment core P2 was collected and studied from an exposed swampy area (figure 1a) with an objective to understand the salinity pattern and vegetation succession in the estuary. The site P2 is located in the central part of Pichavaram estuary and is mainly inhabited by Avicennia officinalis, A. marina and Suaeda sp. with fringes of Rhizophora sp. along the backwater channel (figure 1c). The sediment core was obtained using hand operated augur cum piston corer (Eijelkamp, Netherlands). Immediately after collection, the cores were sub-sampled at $2 \mathrm{~cm}$ and $5 \mathrm{~cm}$ interval, respectively. The samples were stored in air-tight polythene bags without any preservative. ${ }^{14} \mathrm{C}$ dates of the organic carbon were obtained from Birbal Sahni (BS) Institute of Palaeobotany, India and calibrated following Stuiver et al. (1998). In laboratory, sediment colour was identified using Munsell colour chart (Munsell and Farnum 1941) and texture was analyzed on the basis of percentage of sand in the sediment following soil density method (USDA 1992). Salinity was measured in $10 \mathrm{~g}$ of air dried soil sample dissolved in $100 \mathrm{ml}$ of deionized water. The samples were homogenized for $30 \mathrm{~min}$ utes before measuring the salinity using 'Orion-5 star (Thermo-Orion, Scientific Equipment, USA) at standardized $25^{\circ} \mathrm{C}$ temperature.

For palynological and thecamoebian study, $10 \mathrm{~g}$ soil samples were treated with warm $10 \%$ potassium hydroxide and later sieved through 150 mesh (105 $\mu \mathrm{m})$. The filtrate was settled overnight and the supernatant drained. The residue was treated with $40 \%$ Hydrofluoric acid. The sample was then acetolysed, following Faegri and Iverson (1989). The acetolysed samples were passed through 650 mesh $(10 \mu \mathrm{m})$ and the residue was mounted on glass slides in glycerine jelly for study. The samples were studied under a high power light microscope (Olympus BX-52). Pollen atlases of Thanikaimoni (1966), Thanikaimoni et al. (1973), Tissot et al. (1994) and reference slides from the Herbarium of Birbal Sahni Institute of Palaeobotany were consulted for the identification of palynomorphs. The pollen/spore spectra prepared is the percentage of total palynological counts in the air dried $10 \mathrm{~g}$ sample. The minimum pollen sum of 300 grains was aimed, but this was not achieved in all samples. Data is represented in the pollen diagram as an average percentage of the pollen sum and arranged in different groups such as 


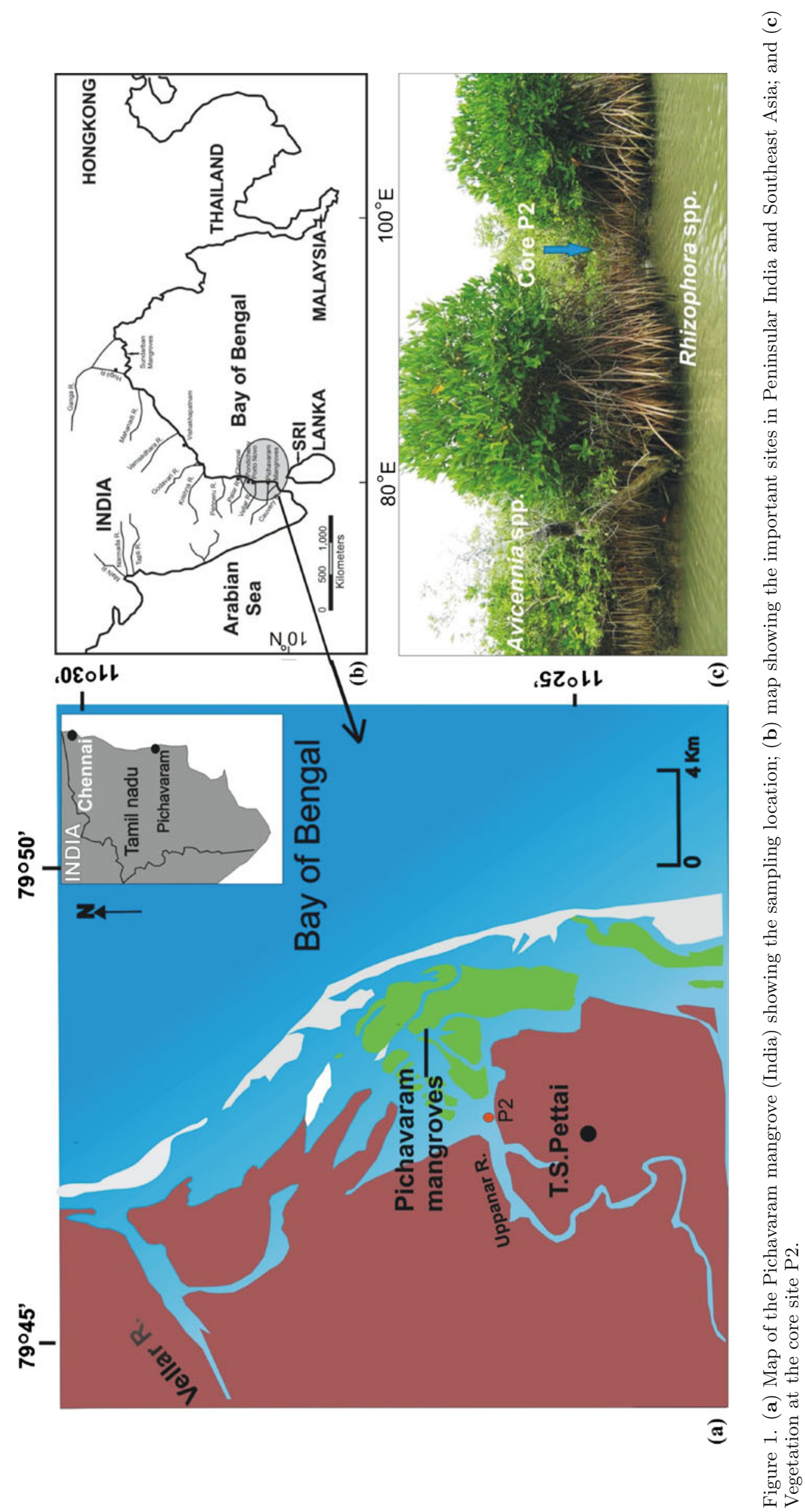


mangroves, evergreen/moist deciduous, dry deciduous (Champion and Seth 1968) and nonarboreal taxa. Various non-pollen palynomorphs such as freshwater algae, thecamoebians (Ogden and Hadley 1980; Patterson and Kumar 2002), dinoflagellate cysts, foraminiferal linings, pteridophytic and fungal spores were also studied but were not included in the pollen sum.

\section{Results and discussion}

The age of the oldest sediment in the core P2 is 3700 cal years BP. In order to express the finer biostratigraphic units and to decipher significant events and episodes since the time of deposition of these sediments, the whole pollen diagram has been classified into four pollen zones in ascending chronological sequence. All the pollen zones have been prefixed with site initials, P2-I to P2-IV.

\subsection{Core P2}

4.1.1 Pollen zone P2-I (250-200 cm): Rhizophoraceae-Avicennia-Sonneratia-ExcoecariaBarringtonia-Hopea-Euphorbiaceae-AsteraceaeSolanum-Cyperaeae-Cheno/Ams-fernsEichhornia-Typha-Pediastrum-Thecamoebian assemblage

This zone spanning 1600 years between ca. 3700 and 2100 cal years BP encompasses a $50 \mathrm{~cm}$ deep sediment layer. The basal part of the profile recorded an average salinity of 3.2 , a sandy clay sediment texture (figure 2) with sand (41.5\%),

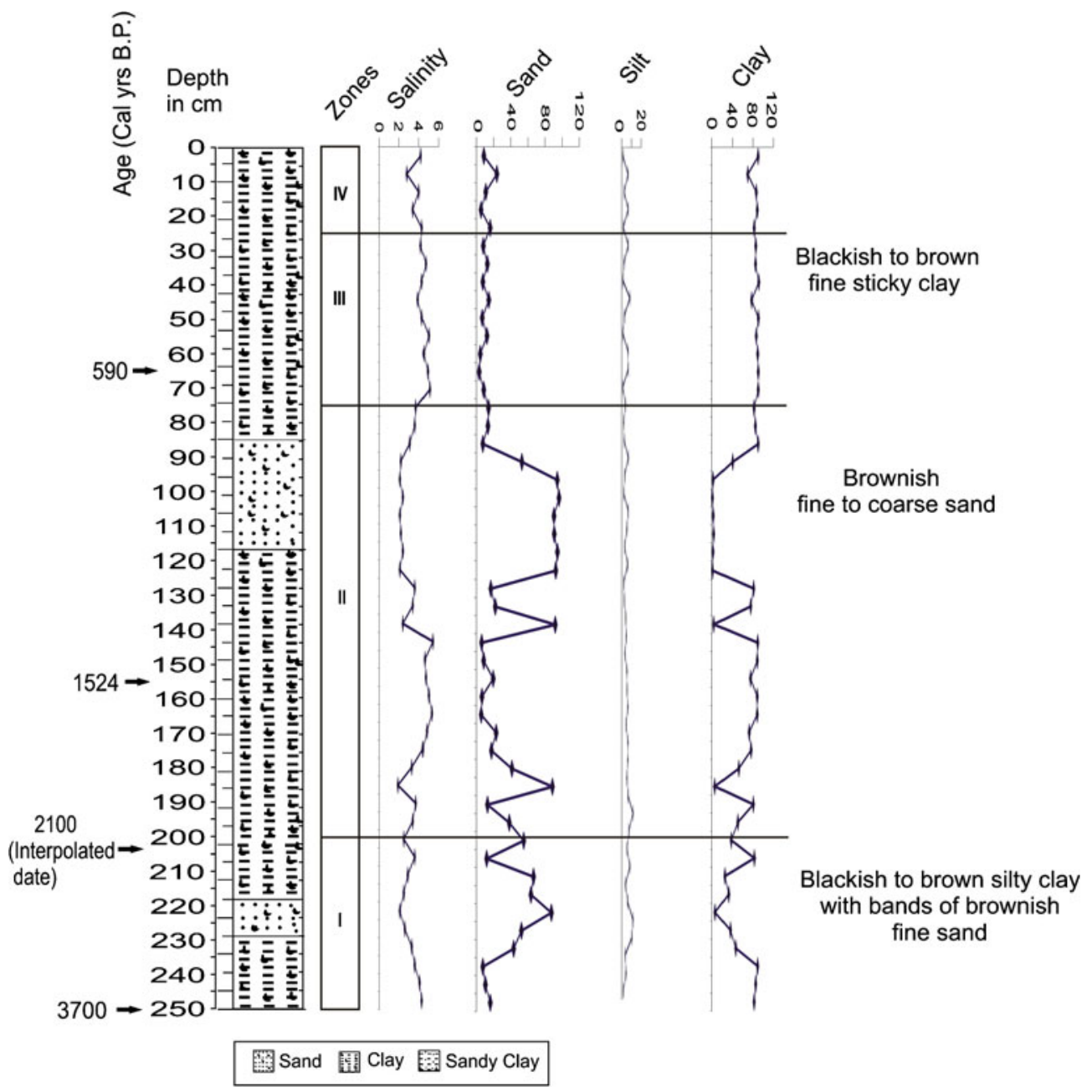

Figure 2. Sediment parameters of the core P2 from Pichavaram estuary, India. 
silt $(6.2 \%)$ and clay (52.3\%) and 5Y2/2 (blackish) Munsell colour code. The latter part of the zone $(\sim 3000$ yrs BP) shows an average salinity of 3.3 in the aqueous soil solution with a maximum of 3.3 and a minimum of 2.1 in clayey sediment with a Munsell colour code of $5 \mathrm{Y} 3 / 2$ (table 1 ). The salinity result suggests a stabilized estuarine ecosystem with a mixed water column as evidenced by the presence of signatures of marine dinoflagellate cysts $(4.8 \%)$ such as Spiniferites, Operculodinium and brackish water foraminiferal chitinous linings (25.8\%) of Ammonia. The zone shows dominance of mangroves (29.9\%) mainly Rhizophora sp., Sonneratia apetala, S. caseolaris, Avicennia marina, A. officinalis, Bruguiera cylindrica, Ceriops decandra, Lumnitzera racemosa, Excoecaria agallocha, Nypa fruticans and Acanthus ilicifolius. The non-mangrove tree pollen taxa includes Anacardium occidentale, Apocynaceae, Barringtonia racemosa, Cedrela odorata, Hopea and other Dipterocarpaceae members, Azadirachta indica, Artocarpus heterophyllus, Palmae, Sapotaceae, Syzygium gardneri, Conocarpus erectus, Mallotus beddomei, Hibiscus tiliaceus and Thespesia populnea whereas the nonarboreals (7.1\%) include Asteraceae, Artemisia nilagirica, Caryophyllus, Convolvulus alsinoides, Clerodendrum inerme, Derris trifoliata, Liliaceae Urtica dioica and Solanum nigrum (figure 3a). The presence of fungal spores $(21.7 \%)$ and pteridophytic fern spores (10.2\%) along with Poaceae/Cyperaceae and Cheno/Ams (43.5\%) together suggests a stabilized climate that favoured evergreen/moist deciduous forest characterized by Dipterocarpaceae and Sapotaceae members $(13.9 \%)$ along with a sparse dry deciduous forest marked by Mallotus and Conocarpus (5.0\%). Presence of macrophytes (1.0\%) such as Eichhornia and Typha along with algae (16.5\%) Pediastrum, Coelastrum, Botryococcus and thecamoebians (21.0\%) like Cyclopyxis, Nebela and Arcella indicate freshwater input in the ecosystem from land (figure $3 \mathrm{~b}$ ). All the above evidences indicate a warm and humid climate with a strong monsoon leading to an oligosaline condition.
4.1.2 Pollen zone P2-II (200-75 cm): Avicennia-Suaeda-Meliaceae-EuphorbiaceaeBorreria-Justicia-Liliaceae-Poaceae/CyperaceaePediastrum-Cyclopyxis-marine dinoflagellate cysts-Ammonia lining assemblage

This zone lasted for about 1480 years between ca. 2100 and 620 cal years BP and is characterized by the very rapid deposition of $125 \mathrm{~cm}$ of sediment. The zone shows clay to sandy clay texture with sand $(43.6 \%)$, silt $(4.8 \%)$ and clay $(51.7 \%)$ and a Munsell colour code of 5 Y3/2 (blackish to brown). It reveals the abundance of mangroves (39.1\%), mainly the salt tolerants such as Avicennia marina and Suaeda spp. along with some true mangroves like Sonneratia apetala, S. caseolaris, Ceriops decandra, Excoecaria agallocha and mangrove associate Acanthus ilicifolius. The maximum salinity of the aqueous soil solution is 3.6 and a minimum of 2.5 leading to an average salinity of 2.8 suggesting an oligosaline condition. Other tree taxa include Azadirachta indica, Dipterocarpus spp., Artocarpus heterophyllus, Sapotaceae, Casuarina equisetifolia, Terminalia arjuna and Mallotus beddomei. A good percentage of nonarboreal taxa $(8.3 \%)$ such as Asteraceae, Borreria, Caryophyllus, Boerhavia, Derris trifoliata, Justicia betonica, Liliaceae, Polygonum, Solanum nigrum, Tabernaemontana gamblei and ubiquitious taxa (33.2\%) like Poaceae/Cyperaceae along with fungal (20.8\%) and pteridophytic spores $(13.1 \%)$ indicate a mixed forest with the presence of both moist (15.4\%) and dry deciduous $(3.8 \%)$ taxa along with a greater diversity of non-arboreals. The presence of Casuarina equisetifolia in the latter part of the zone is a good indicator of human impact on the study area. Low percentage of freshwater forms like the macrophyte Eichhornia $(0.2 \%)$ and Pediastrum boryanum (6.0\%), wide fluctuations in the dominance of thecamoebian (34.8\%) like Arcella, Cyclopyxis and Nebela along with their marine counterparts Ammonia linings (19.1\%) throughout the zone suggests climatic amelioration from warm and humid to dry and arid. Emergence of organic-walled dinoflagellate cysts of Spiniferitis

\begin{tabular}{|c|c|c|}
\hline Phase & $\begin{array}{l}\text { Depth }(\mathrm{cm}) \\
\quad(\mathrm{cm})\end{array}$ & Description \\
\hline IV & $0-25$ & Blackish-to-brown $(5 Y 3 / 2)$ fine sticky clay \\
\hline III & $25-75$ & $\begin{array}{l}\text { Brownish }(5 \mathrm{Y} 4 / 2) \text { fine-to-coarse sand punctuated by } \\
\text { broad to thin bands of blackish to brown sticky clay }\end{array}$ \\
\hline II & $75-200$ & $\begin{array}{l}\text { Blackish-to-brown }(5 \mathrm{Y} 2 / 2) \text { silty clay with } \\
\text { brownish fine sand }(5 \mathrm{Y} 4 / 2)\end{array}$ \\
\hline $\mathrm{I}$ & $200-250$ & Blackish-to-brown $(5 \mathrm{Y} 2 / 2)$ silty clay \\
\hline
\end{tabular}



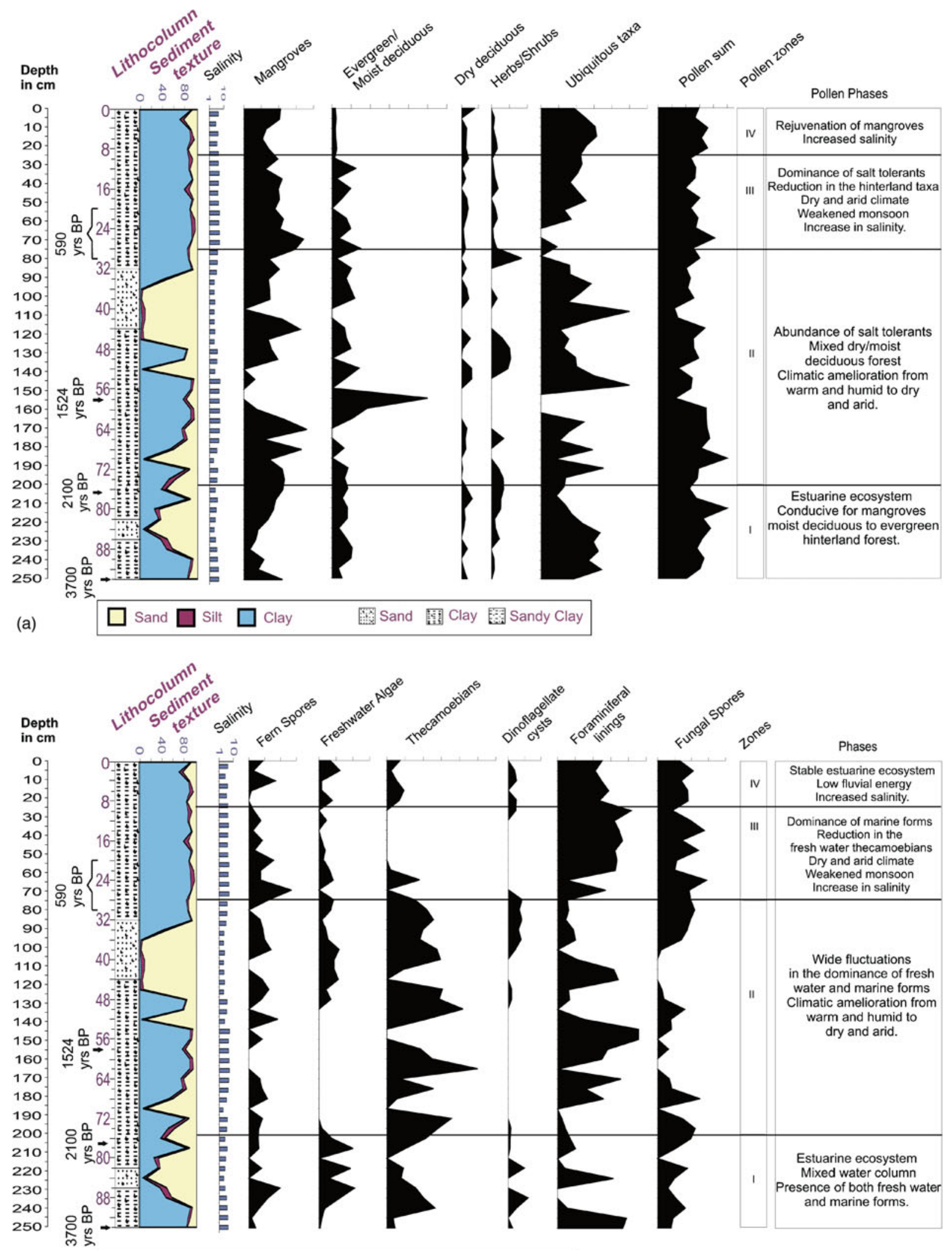

(b)

Figure 3. Percentage count of (a) total pollen palynomorphs and (b) non-pollen palynomorphs in core P2 of Pichavaram estuary, Tamil Nadu. 
and Operculodinium in the latter part of the zone ( 1000 yrs BP) depicts marine incursion due to drier conditions.

\subsubsection{Pollen zone P2-III (75-25 cm): Avicennia- Sonneratia-Palmae-Casuarina-Asteraceae- \\ Liliaceae-Cheno/Ams-Poaceae/Cyperaceae-marine foraminiferal linings}

This zone lasted about 420 years between ca. 620 and 200 cal years BP and encompasses $50 \mathrm{~cm}$ of sediment. The average salinity of the aqueous soil solution of the sediment in this zone is 4.5 with a maximum of 5.1 and a minimum of 3.9. The sediment reveals a silty clay texture with sand $(4.0 \%)$, silt $(28.6 \%)$ and clay $(67.4 \%)$ and the Munsell colour code for this zone is $5 \mathrm{Y} 3 / 2$ (blackish brown). A good percentage of salt tolerant mangroves (41.4\%) such as Avicennia and Suaeda as compared to other mangroves like Sonneratia apetala, $S$. caseolaris, Ceriops decandra and Excoecaria agallocha along with the non-mangrove tree pollen like Cedrela odorata, Palmae, Sapotaceae, Casuarina equisetifolia indicating anthropogenic activity, Conocarpus erectus, Mallotus beddomei, Pinus, Scyphiphora hydrophyllacea along with nonarboreals $(3.2 \%)$ such as Asteraceae, Justicia betonica, Liliaceae, Scrophulariaceae, Solanum nigrum, Ocimum sanctum $\sim 450$ yrs $\mathrm{BP}$ and ubiquitious taxa (47.8\%) like Poaceae/Cyperaceae along with fungal $(17.8 \%)$ and pteridophytic spores $(11.4 \%)$ indicates a mixed forest with low diversity of evergreen/moist deciduous (12.3\%) taxa represented by Meliaceae and Anacardium pollen and dry deciduous (4.6\%) taxa marked by Casuarina equisetifolia and Euphorbiaceae. The dominance of Ammonia foraminiferal linings (51.6\%) along with less abundant dinoflagellate cysts $(1.4 \%)$ and a reduction in the freshwater thecamoebians $(2.9 \%)$ and other aquatic taxa (4.8\%) indicates a dry and arid climate due to weakened monsoon with an increase in salinity.

\subsubsection{Pollen zone P2-IV (25-0 cm):} Avicennia-Rhizophoraceae-Poaceae/CyperaceaeCheno/Ams-thecamoebian-marine foraminiferal linings-dinoflagellate cysts

This zone covered $25 \mathrm{~cm}$ of sediment and spanned from 200 cal years BP until the present. The average salinity of the aqueous soil solution is 3.7 with a maximum of 4.3 and a minimum of 2.8. It represents a clayey texture with sand $(12.9 \%)$, silt $(3.6 \%)$ and clay $(83.4 \%)$ and a Munsell colour code of $5 \mathrm{Y} 3 / 2$ (blackish to brown). This zone shows the abundance of mangroves (30.6\%) mainly the salt tolerants such as Avicennia and Suaeda and a lower percentage of Rhizophora sp., Sonneratia apetala and Excoecaria agallocha. Low percentage of hinterland tree taxa such as Apocynaceae, Azadirachta indica, Syzygium gardneri, Palmae, Rosaceae, Casuarina, Caesalpinia bonduc, Mallotus beddomei, Hibiscus tiliaceus, Pinus and nonarboreal taxa (3.7\%) like Asteraceae, Caryophyllus, Clerodendrum inerme, Derris trifoliata and Solanum nigrum along with ubiquitous taxa (53.0\%) like Poaceae/Cyperaceae reveals an open forest condition with less abundant evergreen/moist deciduous (5.1\%) and dry deciduous (6.7\%) forest. Low abundance of aquatic taxa like Typha (0.8\%), alga Pediastrum boryanum $(9.6 \%)$ and thecamoebian (10.4\%) Cyclopyxis indicates a lotic condition with low fresh water influx whereas a good percentage of chitinous linings of Ammonia (40.0\%) and dinoflagellate cysts (3.8\%) depict marine influx in the ecosystem suggesting a climate less wet and humid than pollen zone II with weak monsoon leading to an increase in salinity.

\section{Development of the vegetation}

Lithofacies analysis, geochemical analysis, pollen assemblages and radiocarbon dates of the sediment core P2 from Pichavaram estuary has been used to infer the evolutionary history of the Late Holocene vegetation succession.

\subsection{Zone I (Upland forest + mangroves)}

This zone shows an unstable depositional environment evidenced by heterogeneous sediment constituting fine silty clay with occasional bands of fine sand. Core P2 shows the presence of sand at $220 \mathrm{~cm}$ interspersed between the broader clay bands which indicate a high fluvial energy condition in the ecosystem. Salinity also showed a fluctuating condition with higher in the clayey layer and lower in the sandy band. Presence of mangroves along with a good percentage of hinterland moist deciduous and evergreen taxa indicates a warm and humid climate with a strong monsoon condition. A good percentage of freshwater thecamoebians along with marine dinoflagellate cysts and foraminiferal linings depicts an estuarine condition. The present study shows an estuarine ecosystem in Zone I due to high tidal influx as well as good freshwater run-off from land with a relatively high fluvial energy indicating a strong monsoon condition. Warm and humid climate around 5000 yrs BP (Vishnu-Mittre and Sharma 1975; Singh et al. 1974; Bhattacharya and Chauhan 1997) and dry and cool around 1500 yrs BP from southern India has also been accounted (Bera et al. 1995, 1997; Bera and Farooqui 2000). 


\subsection{Zone II (Mixed forest + back mangroves)}

Zone II shows heterogeneous sediment constituting fine silty clay with occasional bands of sand which indicates a high fluvial energy condition at $140 \mathrm{~cm}$ and $185 \mathrm{~cm}$ interspersed between the broader clay bands indicating low fluvial energy in the ecosystem (figure 3a). Salinity also shows a fluctuating condition with higher in the clayey region and lower in the sandy bands. The presence of a broad band of sandy sediment from 125 to $95 \mathrm{~cm}$ reveals high tidal influx with a low salinity due to larger pore size of sand particles which does not allow the accumulation of salts in the sediment causing downward percolation of salts in the deeper layers. This part of the core also showed a comparatively less percentage of palynotaxa along with other biotic forms which indicates a fluctuating condition of an estuarine ecosystem. The zone shows an unstable depositional environment with wide fluctuations in salinity along with abundance of salt tolerants like Suaeda spp., back mangroves and a mixed forest dominated by mixed deciduous taxa due to occasional high tidal influx and freshwater input from land suggesting a climatic amelioration from warm and humid to a comparatively drier environment. A gradual weakening of Asian summer monsoon between 3700 and 1500 cal yr $\mathrm{BP}$ has been reported from lower and middle latitudes in India and China (Selvaraj et al. 2008; Liu et al. 2009) which attributes to the change in climate in the present study area. This weakening of monsoon is generally interpreted as a response to decreasing summer insolation (Overpeck et al. 1996).

\subsection{Zone III (Open forest + salty marshes)}

This zone in core P2 shows a stabilized ecosystem with the overall dominance of fine sticky clay sediment with an increased salinity condition. Clay due to its strong tendency to bind with salts caused the accumulation of salts in the sediment layers leading to an increased salinity condition. The entire zone shows the dominance of salt tolerant Suaeda spp. along with hinterland taxa and a good percentage of foraminiferal linings with a decline in the fresh water thecamoebians. The dominance of salt tolerant species along with foraminiferal linings and a decline in true mangroves and freshwater forms together indicate that the fluvial process in the river system was weak, perhaps responding to weak monsoon and drier climates. Several records using varied proxies from Asia and Africa also show a severe and lasting drought during MiddleLate Holocene (Booth et al. 2005; Kaniewski et al. 2008).

\subsection{Zone IV (Open forest + mangroves + salty marshes)}

Zone IV in core P2 again shows the dominance of fine sticky clay sediment with a short span of high fluvial energy at $15 \mathrm{~cm}$ depth in the last millennium. High salinity in the present zone may be attributed to the high temperature conditions coupled with weakened monsoon favouring higher rate of evaporation in the soil. In clayey soil, salt accumulation is common due to the development of strong aggregates which causes less percolation of salts into the deeper layers leading to a hypersaline condition in the clayey fractions. The presence of true mangroves along with the salt tolerant species and a lower percentage of thecamoebians indicate a warm and humid climate leading to a stabilized estuarine condition. Hence this zone is characterized by rejuvenation of true mangroves and a high percentage of salt tolerant plants with low percentage of thecamoebians thereby indicating a less wet and humid climate than Zone I induced by weakened monsoon and enhanced anthropogenic activity. The pollen/spore study from the lacustrine sediments in south-western ghats, India also confirms a reduction in rainfall and arid climatic conditions in the beginning of Late Holocene which gradually ameliorated to warm and humid conditions until 780 yrs BP (Bera and Farooqui 2000). Earlier records also suggest monsoonal circulation and intensification since 1500 yrs BP and reduction during Little Ice Age in the records from Dandak, India (Sinha et al. 2007), Dongge (Wang et al. 2005) and Yemen and Oman Margin (Fleitmann et al. 2003).

\section{Conclusion}

Palynostratigraphical and geochemical evidences from Pichavaram estuary show that during the past 3 millennium the climate has ameliorated from warm and humid to comparatively drier condition. Consequently, the vegetation too evolved from moist deciduous/evergreen forest to mixed deciduous forest. The qualitative and quantitative study shows a decline in the mangrove diversity which may be attributed to the increased salinity conditions in the north-eastern part of Pichavaram estuary making it highly vulnerable for the mangroves. This is reflected by the dominance of salt tolerant mangrove associates in the area since the last millennium which is attributed to the increased anthropogenic activities in the upland areas and restriction of fresh water by damming in paddy fields and aquaculture, etc., which is eventually increasing the salinity in the estuary. 


\section{Acknowledgements}

The authors are grateful to the Director, BSIP for encouragement and the facilities to accomplish the work. One of the authors Jyoti Srivastava thanks the Department of Science Technology for financial support as JRF.

\section{References}

Bera S K and Farooqui A 2000 Mid-Holocene vegetation and climate of south Indian Montane; J. Paleontol. Soc. India 45 49-56.

Bera S K, Farooqui A and Gupta H P 1997 Late PleistoceneHolocene vegetation and environment in and around Marian Shola, Palni Hills, Tamil Nadu; Palaeobotanist 46 191-195.

Bera S K, Gupta H P and Farooqui A 1995 Berijam Lake: 20,000 yrs. Sequence of paleofloristics and paleoenvironment in Palni Hills, South India; Geophytology 26 99-104.

Bhattacharya A and Chauhan M S 1997 Vegetational and climatic changes during recent past around Tipra Bank Glacier, Garhwal Himalaya; Curr. Sci. 72 408-411.

Booth R K, Jackson S T, Forman S L, Kutzbach J E, Bettis E A, Kreig J and Wright D K 2005 A severe centennialscale drought in mid-continental North America 4200 years ago and global linkages; The Holocene 15 321-328.

Champion H G and Seth S K 1968 A revised survey of the forest types of India; Manager of Publications, Delhi, India.

Faegri K and Iverson J 1989 Textbook of Pollen Analysis; Wiley, Chicester.

Farooqui A and Achyuthan H 2006 Evidences of middle to late holocene vegetation in Adyar Estuary, Chennai; J. Geol. Soc. India 68 230-238.

Farooqui A and Vaz G G 2000 Holocene sea-level and climate fluctuations: Pulicat lagoon - A case study; Curr. Sci. 79(10) 1484-1488.

Ferdin M, Görlitz S and Schwörer S 2010 Water stress in the Cauvery basin, south India. How current water management approaches and allocation conflict constrain reform; ASIEN: German Journal for Politics, Economy and Culture 117 27-44.

Fleitmann D, Burns S J, Mudelsee M, Neff U, Kramers J, Mangini A and Matter A 2003 Holocene forcing of the Indian monsoon recorded in a stalagmite from Southern Oman; Science 300 1737-1739.

Kaniewski D, Paulissen E, Van Campo E, Al-Maqdissi M, Bretschneider J and Lerberghe K V 2008 Middle east coastal ecosystem response to middle-to-late Holocene abrupt climatic changes; PNAS 105(37) 13,941-13,946.

Kathiresan K 2000 A review of studies on Pichavaram mangroves, southeast India; Hydrobiologia 430 185-205.

Klekowski E J, Lowenfeld R L and Hepler P K 1994 Mangrove genetics II. Outcrossing and lower spontaneous mutation rates in Puerto Rican Rhizophora; Int. J. Plant Sci. 155 373-381.

Liu X, Dong H, Yang X, Herzschuh U, Zhang E, Stuut Jan-Berend W and Wang Y 2009 Late Holocene forcing of the Asian winter and summer monsoon as evidenced by proxy records from the northern Qinghai-Tibetan Plateau; Earth Planet. Sci. Lett. 280(1-4) 276-284.

Munsell A H and Farnum R B 1941 A color notation: An illustrated system defining all colors and their relations; Kessinger Publishing.

Ogden C G and Hadley R H 1980 An atlas of freshwater Testate Amoeba; British Museum of Natural History and Oxford University Press, London and Oxford, UK.

Overpeck J, Anderson D, Trumbore S and Prell W 1996 The southwest Indian monsoon over the last 18,000 years; Clim. Dyn. 12 213-225.

Patterson R T and Kumar A 2002 A review of current testate rhizopod (thecamoebian) research in Canada; Palaeogeogr. Palaeoclimatol. Palaeoecol. 180 225-251.

Ramanathan A L 1997 Sediment characteristics of the Pichavaram mangrove environment; Indian J. Marine Sci. 26 319-322.

Saenger P 2002 Mangrove Ecology, Silviculture and Conservation; Kluwer, Dordrecht.

Selvam V 2003 Environmental classification of mangrove wetlands of India; Curr. Sci. 84(6) 757-765.

Selvaraj K, Chen C T A and Lou J Y 2008 Holocene east Asian monsoon variability: Links to solar and tropical Pacific forcing; Clim. Past Discuss. 4 929-953.

Seralathan P, Sreenivasulu S, Ramanathan A L, Rajamanickam G V, Nagendra R, Singarasubramaniam S R, Mukesh M V and Manoharan K 2006 Post-tsunami sediment characteristics of Tamilnadu coast; In: Tsunami: Causes, effects remedial measures, pre and post tsunami disaster management: A geoscience perspective (ed.) Rajamanikkam G V, 26th December 2004, Department of Science and Technology Report, New Delhi, pp. 196-209.

Singh G, Joshi R D, Chopra S K and Singh A B 1974 Late Quaternary history of vegetation and climate of the Rajasthan desert, India; Phil. Trans. Roy. Soc. London 267 467-501.

Sinha A, Cannariato K G, Stott L D, Cheng H, Edwards R L, Yadava M G, Ramesh R and Singh I B 2007 A 900 year (600 to 1500 A.D.) record of the Indian summer monsoon precipitation from the core monsoon zone of India; Geophys. Res. Lett. 34, doi: 10.1029/2007GL030431.

Stuiver M, Reirner P J and Braziunas T F 1998 Highprecision radiocarbon age calibration for terrestrial and marine samples; Radiocarbon 40 1127-1151.

Thanikaimoni G 1966 Contribution a I'etude palynologique des Palmiers. Inst. Fr. Pondichery, Tray; Sect. Sci. Tech. 2 1-92.

Thanikaimoni G, Caratini C and Blasco F 1973 Relation between the pollen spectra and the vegetation of a south Indian mangrove; Pollen Spores 15 281-292.

Tissot C, Chikhi H and Nayar T S 1994 Pollen of wet evergreen forests of the Western Ghats, India; Institut Français, Pondicherry, India.

USDA 1992 Soil Conservation Service. Soil Survey Laboratory Methods Manual; United States Dept. of Agriculture, Soil Surv. Invest. Report. No. 42. Washington DC.

Vishnu-Mittre and Sharma C 1975 Pollen analysis of the salt flat at Malwan, Gujarat; Palaeobotanist 22 118-123.

Wang Y J, Cheng H, Edwards R L, He Y Q, Kong X G, An Z S, Wu J Y, Kelly M J, Dykoski C A and Li X D 2005 The holocene Asian monsoon: Links to solar changes and North Atlantic climate; Science 30(5723) 854-857. 